\title{
ECONOMIC ASPECTS OF REDUCING LOW-STACK EMISSION IN POLAND
}

doi: $\quad 10.2478 /$ czoto-2019-0044

Date of submission of the article to the Editor: $07 / 11 / 2018$

Date of acceptance of the article by the Editor: 10/12/2018

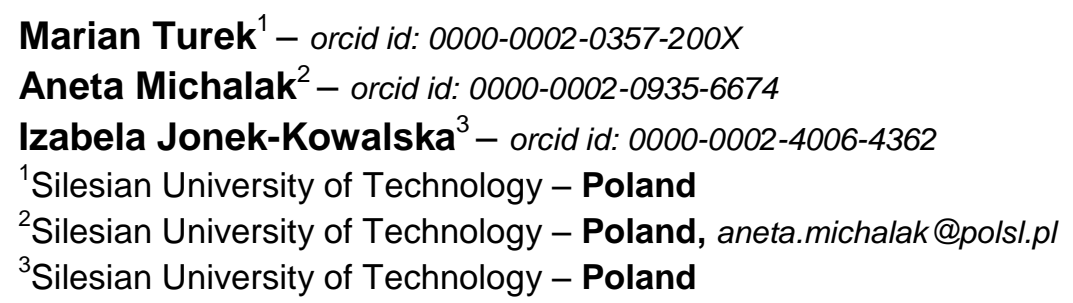

Abstract: The objective of the paper is to present the problem of low-stack emission in the economic and financial context. The paper presents the results of preliminary research based on literature review and environmental reports. After completing the selection of publications and data extraction, which could help to describe the issue raised, their analysis, comparison and generalization was conducted. The aspects presented may constitute a starting point in building a model of pricing the economic results of low-stack emission. In the first place the phenomenon of smog was subject to analysis, as one of the most significant consequences of low-stack emission, influencing health of human beings, environment and tangible assets. Then an attempt was made to express the previously identified results of low-stack emission in the economic and financial categories, taking into consideration the costs incurred for the purposes of completing the undertakings aimed at decreasing lowstack emission, costs avoided due to the decrease of the number of illnesses caused by low-stack emission, costs avoided due to the restriction of the negative influence of low-stack emission on the environment and on tangible assets as well as economic benefits achieved thanks to the reduction of low-stack emission.

Keywords: low-stack emission; air pollution; costs of reducing low-stack emission

\section{INTRODUCTION}

Air pollution caused by low-stack emission is currently one of the most important problems in our country. Poland, next to Bulgaria, is the most polluted country in the European Union. This problem stopped being an issue raised only by scientists and raised in case of environmental reports, but has become a subject of dynamic social discussion, acquiring a broad environmental, social and economic dimension. In relation to the desire to take decisive actions in order to improve the quality of air by the local authorities, the state authorities as well as by an increasingly large group of people, concerned by the ongoing state of affairs, the topic of reducing low-stack 
emission requires in-depth research. One of the aspects constituting the subject of the research taken up by the Authors is the economic and financial dimension of decreasing low-stack emission in Poland.

\section{METHODOLOGY OF RESEARCH}

The objective of the paper is to present the problem of low-stack emission in the economic and financial context. The paper presents the results of preliminary research conducted on the basis of a review of accessible reports by the organizations dealing with a variety of aspects of air pollution. Furthermore, the current publications were used as well, showing the selected, often narrow areas of the problem of low-stack emission. On these grounds an attempt was made to outline an economic dimension of the problem of low-stack emission.

In the first place the phenomenon of smog was subject to analysis, as one of the most significant consequences of low-stack emission, influencing health of human beings, environment and tangible assets. Next, an attempt was made to express the previously identified results of low-stack emission in the economic and financial categories, taking into consideration the costs incurred for the purposes of completing the undertakings aimed at decreasing low-stack emission, costs avoided due to a decrease of the number of illnesses resulting from low-stack emission, costs avoided due to the restriction of the negative influence of low-stack emission on the environment and on tangible assets as well as economic benefits achieved due to reducing low-stack emission.

In the work literature studies together with the analysis of current reports regarding the issue of the consequences of low-stack emission were used. When choosing the sources among a large number of publications of air quality, especially smog, the ones were selected that referred to the financial aspects of this issue. A significant role in that matter was played by the reports of environmental organizations. For a proper identification of the research problem, it was also referred to literature on the basic regularities occurring in connection to smog. After having selected the publications and data extraction, which could help to describe the issue raised, their analysis, comparison and generalization was conducted.

The paper is of theoretical and cognitive character. It is a preliminary step to build the model of pricing the economic results of low-stack emission.

\section{RESULTS}

As a result of literature studies, conceptualization of smog phenomenon was made. Impact on human health, environment and physical objects was indicated. This impact is subject to further discussion if we attempt to include it in financial terms. The word 'smog' comes from English language and is a combination of the words 'smoke' and 'fog'. Smog is an unnatural atmospheric phenomenon based on coexistence of air pollution due to human activity with harmful natural phenomena: significant fog and windless weather.

The definition of the International Organization for Standardization accepts that 'smog is an extensive pollution of air with aerosols, coming partly from natural processes and partly created due to human action' (Godzik et al., 1995). The term of smog is not strict from scientific point of view. It is a term used mostly for social communication. The term 'smog' is generally used in dissemination of the research results on the degree of air pollution and particularly data acquired through the use of warning 
systems. The functioning of this term as an element of social communication serves mostly to warn about situations that may endanger health and for the mobilization of the society in order to prevent excessive air pollution. Smog in Poland appears mostly in the heating season (September-April) and is caused by the so called low-stack emission (a significant accumulation of emitters at the height of 40 meters above the ground level in places with high density of buildings on small surface).

According to the data contained in the reports concerning the state of the environment published annually by the Chief Inspectorate of Environmental Protection, in the scale of the whole country the percentage share of the individual heating of building in excess of the accepted concentrations of particulate matter PM10 and PM2.5 as well as benzopyrene is within the range of $80-90 \%$. It is caused by using boilers or coal furnaces that do not meet any emission standards, in which the process of burning solid fuels, including mostly hard coal, is conducted in a not very efficient way as well as by burning in the aforementioned heating installation fuels with low quality parameters - with low calorific value and high concentration of sulfur and ash, or even burning waste of various origins (Mokhtar et al., 2014).

The emission generated by individual heating devices of households causes special problems because it comes from many emitters at low height, which is why the pollutants accumulate mainly around the place of origin and, in cases when it is a compact housing area, their influence is even more harmful (Kicinski, 2018). A very high concentration of particulate matter and benzopyrene in combination with harmful meteorological conditions, especially with weak airing, create smog. It should be also added that the creation of low-stack emission is also aided by the industrial pollution and exhaust fumes from the means of communication (Gong et al., 2017).

The World Health Organization described Poland, next to Bulgaria, to be one of two countries of the European Union with the most polluted air. In the ranking of 50 most polluted cities in the countries of the European Union, as many as 33 are from Poland, among which 10 are located in the Silesia province, with Żywiec, Pszczyna and Rybnik at the front of the list (Huete-Morales et al., 2017).

The occurrence of low-stack emission brings various harmful effects. Among the most important ones there are: worsening of human health, formation of environmental damage and destruction of various tangible assets (Sadlok, 2014).

The most perceptible consequence of low-stack emission is its direct influence on the deterioration of the condition of human health. Multiple examples of scientific research confirm the correlation between the higher daily-average concentrations of air pollution and increased number of instances of hospitalizations due to the aggravation of disease symptoms, concerning mainly respiratory system, cardiovascular system, central nervous system disorders, eye diseases, allergic reactions, infertility problems (Ali et al., 2019).

Air pollution caused by the low-stack emission also has a negative effect on the environment. Carbon dioxide and nitrogen oxides emitted, among other pollutants, contribute to the creation of the so called acid rains, that is rain with a decreased $\mathrm{pH}$ in comparison to rain waters in 'normal conditions'. The most serious result of acid rains, and therefore, indirectly, of low-stack emission, is damage to tree leaves and needles, worsening condition of the forests, acidification of the soil (Sensuła, 2016). Another harmful effect is the penetration of the emitted heavy metal particles into soil and waters and by that, indirectly, to living organisms drinking polluted water and 
eating food based on, among others, plants taking water and nutrients from the polluted soil (Okoro et al., 2017).

Furthermore, the results of low-stack emission influence negatively on tangible assets that serve us. The most visible example is the damage facades of building, both residential as well as of public use. They are heavily damaged mostly by sulfur dioxide transforming into sulfuric acid and settling on them. Sulfur and oxygen in various compounds as well as carbon dioxide contained in the products of low-stack emission cause a significant acceleration of the natural process of metal corrosion. It means an increase of the everyday costs of living. The acceleration of corrosion has influence on, for example, increased wear of machines and devices of other kinds that are used every day. It can be observed in such a way that the durability of the devices used in industry or in households is much lower in places that are more vulnerable to air pollution (also pollution caused by low-stack emission).

Another result of low-stack emission, increasing the costs of everyday life, is the acceleration of the destruction of leather, paper or clothes. It turns out that life in cities (and other places) with a severe problem of low-stack emission is much more expensive than in towns with less air pollution (Chen et al., 2012).

To sum up, it may be stated that the influence of low-stack emission has huge consequences in basically every facet of life - both of the society as well as of every human being and each of the problems mentioned above generated by the phenomenon of low-stack emission has a financial and economic dimension.

\section{DISCUSSION}

The actual determination of at least approximate costs of realization of undertakings aimed at decreasing low-stack emission in a given area (of a city, community, province, region, country) is conditioned by a previous determination of (Fig. 1):

- number of furnaces to be removed,

- new source of acquiring thermal energy - connection to the central delivery network, electric, gas or oil furnace installation, heat pumps or coal furnace meeting the emission standards,

- number of people covered by the co-financing for the replacement or utilization of a new source of thermal energy, particularly taking into consideration the so called vulnerable recipients in the understanding of the Energy Law act,

- way and extent of monitoring the effects received.

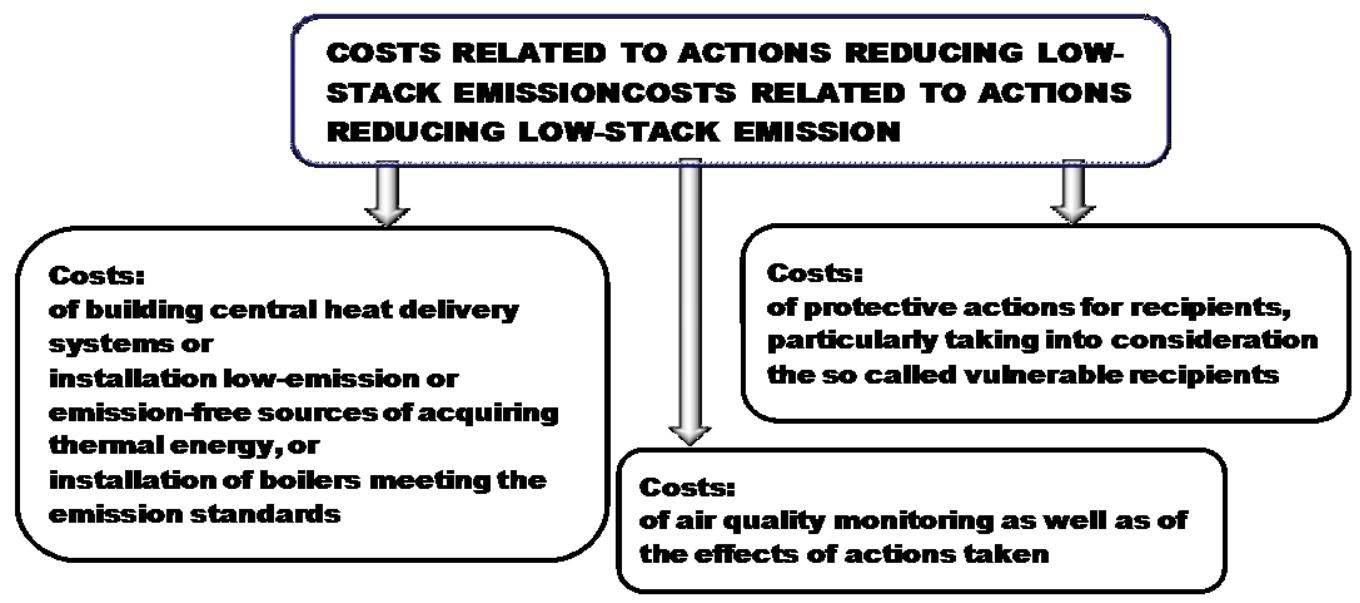

Fig. 1. Costs of decreasing low-stack emission 
The costs of replacement (and of further utilization) are very varied. Undoubtedly, the cheapest solution is the connection to a central heating network or to the supply of domestic hot water. It is only possible in places where such network already exists or is relatively easy to be constructed.

In every other case the replacement costs can be very varied, depending on the accepted way of execution or on the used device. For example, the cost of a coal furnace meeting the emission standards amounts to, depending on heat output, it amounts from 8 to 12 thousand PLN and the heat pumps (the cheapest source of heat in terms of utilization) cost from 20 to even as much as 50 thousand PLN.

As it results from the data above, the costs of replacement and further utilization are high and without financial support, mainly from budgetary resources, impossible to be borne by many people. The problem of the level of co-funding, the number of those eligible to receive it and of the duration in case of subsidizing the costs of exploitation, also requires conducting calculation as precise as possible. Generally, it can be stated that, certainly, in the scale of the country it will be millions of PLN, spent over a period of many years.

For instance, in Katowice, as one of the first cities in Poland a 'Plan of low-emission economy for the city of Katowice' has been designed and is being implemented, in which, among others, the following are accepted:

- improvement of energy effectiveness by the complex thermomodernization of public buildings in the city,

- thermomodernization of public buildings,

- reducing low-stack emission in Katowice - continuation of the actions related to cofunding of the replacement of heat sources in residential buildings,

- reducing low-stack emission in Katowice - continuation of actions related to co-funding of the replacement of heat sources in multifamily building by connecting them to the heating or gas network, while taking into consideration the microgeneration of solar collectors and heat pumps - buildings that are owned or co-owned by Katowice community,

- construction of energy-efficient and passive commercial buildings,

- development of a system of bicycle paths on the premises of the city,

- preparation and conducting social campaigns related to effective and ecological transport,

- decreasing of negative influence of public transport on the natural environment and the improvement of the quality of transport by the purchase of new buses.

These tasks will be executed in major part before the year 2020 and will cost over 2.2 billion PLN, with almost 140 million PLN that will come from the own resources of the city of Katowice (www.teraz-srodowsko.pl, 2017). Beside Katowice, many Polish towns have already developed the low-stack emission counteraction plans and have put considerable sources for this purpose. However, there is still much more to be done in this area (Smurzyńska et al., 2018; Sówka and Bezyk, 2018).

Spending such large amounts of money requires careful monitoring of the way of conducting undertakings related to the reduction of low-stack emission and especially of the effects they bring. In comparison to the costs mentioned above, the monitoring costs can be significantly lower but also need to be included in the calculations (Leśniok, 2011). 
As it was presented above, taking decisive action aimed at decreasing air pollution will be very expensive. However, idleness in this area brings even higher costs and in many cases they may only be calculated in monetary value. It is estimated that air pollution with particulate matter PM2.5 corresponds to close to 0.5 million premature deaths in Europe (over 400000 in 28 countries of the European Union), including almost $80 \%$ of deaths caused by the diseases of the respiratory system and lung cancer (Lee and Wang, 2019; Badyda et al., 2016).

In regards to Poland, in the report of World Health Organization (WHO) from year 2015 it was showed that in year 2010 air pollution contributed to the deaths of 48544 Poles (World Health Organization, 2015). It was not a particularly unfavorable year in terms of emission of pollutants into the air. Therefore, it can be accepted that each year, because of this over 40000 of us die prematurely. How can this be evaluated? We have to realize that the lost years of life also are a cost to the economy and for this reason, to us all. It is estimated based on complicated calculation models using complex algorithms taking into consideration different compounds, referring to, e.g. the costs of failed healing, lost working days. In the report it has been estimated for the amount of almost 101.8 billion dollars.

Air pollution, contributing to the increasing morbidity for various illnesses, also contributes to a significantly lower productivity at work. According to the data passed by the HEAL-Polska organization (HEAL Polska, 2017), due to exposure to harmful substances in the air, health care costs consists also every year of: 12 thousand of new cases of hospitalization, over 500 thousand visits to specialist doctor and as much as 14 million lost working days.

The total value of the external costs of poor air quality in Poland is estimated at the level of 40-120 billion euro yearly. We are threatened therefore by a number of serious consequences from the point of view of our health and budget. Thus, looking for specific solutions that can improve the quality of air that we breathe is justified (Jeschke, 2018).

The costs avoided due to reducing harmful effects of low-stack emission on the environment and tangible assets are very hard to estimate. In some places there is irreversible damage to the nature and priceless monuments. One can only use here examples that illustrate the scale of costs that could have been avoided or limited due to the improvement of the quality of air. For example, in Kraków where the results of low-stack emission are felt particularly strongly and directly influence the condition of the buildings, it is estimated that the expenditures for renovation of the damaged historical buildings equal around 70 million PLN (Szewczyńska et al., 2017). However, the savings achieved due to limiting of the destruction processes can be much higher. Sulfur dioxide, transformed into sulfuric acid destroys not only monuments but also the facades of residential and public buildings. As a result of contact with sulfur the plaster crumbles and falls off, becomes gray, dirty, which is tied to high costs of renovation works. Additional costs, which can be avoided by reducing air pollution, are the costs of the increased wear of metal devices, constructions, e.g. bridges that are subject to corrosion, or the costs of the destruction of wooden elements.

Among the benefits achieved due to reducing low-stack emission there are benefits that are hard to quantify in economic sense, but they bring large profits in the scale of the entire society. These are the benefits related to the improvement in the quality of life of local communities. It manifests itself in a form of increasing outdoor physical 
activity of residents of the given area. That, on the other hand, has bearing on their health, well-being, interpersonal relations, increase of life satisfaction.

The decrease of air pollution can also correspond to measurable economic benefits, related to the development of tourism in the given region. In some regions, tourism industry is often the most important part of the economy, however, the information about air pollution in such places discourage tourists from coming, significantly decreasing income of the residents. The reduction of the low-stack emission resulting in the improvement of climatic conditions can contribute to the development of tourism.

Apart from tourism industry, the restriction of low-stack emission can also influence the development of other segments of the economy, mainly those that directly depend on clean environment (forestry, agriculture, fishery sectors).

Another beneficial phenomenon related to the limiting of low-stack emission is the increase of the investment attractiveness of the region. It depends on many factors, nevertheless, one of the more important ones is the quality of the environment (including air purity). It is a favorable factor for locating service activities and activities based on advanced technologies. Furthermore, investors when selecting locations more and more often pay attention to the quality of air in the context of the issues mentioned above, such as absence of employees, accelerated wear of machines and constructions as well as similar phenomena that are the effect of air pollution.

\section{CONCLUSION}

About the glass that has been half-filled with water it can be said that it is 'half-full', but also that it is 'half-empty'. This 'half' means that the complex actions aimed at decreasing low-stack emission are practically impossible to be completed because they are very costly and require enormous financial resources.

But certainly the time has come to deal with the empty part of 'half empty glass': premature death of tens of thousands of people as well as money spent on treatment and removing other effects of low-stack emission, and also the enormous cost and constant losses, frequently irreversible.

It would be definitely more beneficial to even invest significant financial resources in the improvement of the current condition, resulting in good quality of air, which we all breathe. Of course, it requires a change in the current way of thinking. But we need to remember that the money, invested in a well thought way in undertakings decreasing low-stack emission, is not wasted - it will return to us, mainly in the form of better health for us all.

Unfortunately, a great investment limitation in low-stack emission reduction is the difficulty to measure the results obtained, with very costly inputs. Therefore, one should lead to the most detailed possible description of the negative financial effects of low-stack emission, in all the areas of life indicated in the paper. A desirable solution would be to create a universal model of calculation encompassing, on the one hand, the outlays of the reduction of low-stack emission, on the other hand, allowing the calculation of the measurable financial benefits obtained, both in the area of health protection, environment, material goods and in other areas of social life and economic activity. 


\section{ACKNOWLEDGEMENTS}

The paper was financed by the sources of the Silesian University of Technology, within the frames of the statutory work no. BK-231/ROZ1/2018 (13/010/BK_18/0029).

\section{REFERENCES}

Ali, Y., Razi, M., De Felice, F., 2019. A VIKOR based approach for assessing the social, environmental and economic effects of smog on human health. Science of the Total Environment, Vol. 650, 2897-2905.

Badyda, A., Gayer, A., Czechowski, P.O., Majewski, G., Dąbrowiecki, P., 2016. Pulmonary Function and Incidence of Selected Respiratory Diseases Depending on the Exposure to Ambient PM10. Iriti M, ed. International Journal of Molecular Sciences 17 (11).

Chen, Y.-L., Shih, Y.-H., Tseng, C.-H., Kang, S.-Y., \& Wang, H.-C., 2012. Economic and health benefits of the co-reduction of air pollutants and greenhouse gases. Mitigation and Adaptation Strategies for Global Change, 18(8), 1125-1139.

Godzik, S., Hławiczka, P., Poborski, P., 1995. Smog - przyczyny - skutki przeciwdziałania. Państwowa Inspekcja Ochrony Środowiska: Warsaw, Poland, pp.7 [In Polish].

Gong, J., Hu, Y., Liu, M., Bu, R., Chang, Y., Li, C., Wu, W., 2017. Characterization of Air Pollution Index and Its Affecting Factors in Industrial Urban Areas in Northeastern China. Polish Journal of Environmental Studies 24 (4), 1579-159.

HEAL Polska, 2017. www.waznamisjazdrowaemisja.pl/wywiady/ile-kosztuje-nasniska-emisja/ (accessed on 15th June 2017) [In Polish].

Huete-Morales, M., Quesada-Rubio, J., Navarrete-Alvarez, E., Rosales-Moreno, M., Dei-Moral-Avila, M., 2017. Air Quality Analysis in the European Union. Polish Journal of Environmental Studies 26 (3), 1579-159.

Jeschke, A., 2018. Public policy against smog in Poland. Alergoprofil, 14(2), 41-44.

Kiciński, J., 2018. Smog - Poland's pressing problem. Anti-smog technologies. E3S Web of Conferences, 46, 00027.

Lee, Ch., Wang, K., 2019. Nash marginal abatement cost estimation of air pollutant emissions using the stochastic semi-nonparametric frontier. European Journal of Operational Research, Vol.: 273, Issue 1, 390-400.

Leśniok, M., 2011. Changeability of Air Pollution in Katowice Region (Central Europe, Southern Poland). Advanced Air Pollution.

Mokhtar, M.M., Hassim, M.H., Taib, R.M., 2014. Health risk assessment of emissions from a coal-fired power plant using AERMOD modelling. Process Safety and Environmental Protection, 92(5), 476-485.

Okoro, H., Orimolade, B., Adebayo, G., Akande, B., Ximba, B., Ngila, J., 2017. An Assessment of Heavy Metals Contents in the Soil around a Cement Factory in Ewekoro, Nigeria Using Pollution Indices. Polish Journal of Environmental Studies 26 (1), 221-228.

Sadlok, R. (ed.), 2014. Przeciwdziałanie niskiej emisji na terenach zwartej zabudowy mieszkalnej. Stowarzyszenie na rzecz efektywności energetycznej i rozwoju odnawialnych źródeł energii „HELIOS”: Bochnia, Poland [In Polish].

Sensuła, BM., 2016. The Impact of Climate, Sulfur Dioxide, and Industrial Dust on $\delta^{18} \mathrm{O}$ and $\delta^{13} \mathrm{C}$ in Glucose from Pine Tree Rings Growing in an Industrialized Area in the Southern Part of Poland. Water, Air, and Soil Pollution 227 (4), 227-106. 
Smurzyńska, A., Czekała, W., Hektus, P., Marks, S., Mazurkiewicz, J., Brzoski, M., Chełkowski, D., Kozłowski, K., 2018. Poznań Air Pollution Analysis for 20152017. Journal of Ecological Engineering, Vol. 19, Issue 6, 162-169.

Sówka, I., Bezyk, Y., 2018. Greenhouse gas emission accounting at urban level: A case study of the city of Wroclaw (Poland). Atmospheric Pollution Research, 9(2), 289-298.

Szewczyńska, M., Dąbrowska, J., Pyrzyńska, K., 2017. Polycyclic Aromatic Hydrocarbons in the Particles Emitted from the Diesel and Gasoline Engines. Polish Journal of Environmental Studies 26 (2), 801-807.

World Health Organization, 2015. Economic cost of the health impact of air pollution in Europe. Copenhagen, Denmark.

www.teraz-srodowisko.pl/aktualnosci/Ponad-2-mld-zl-na-PGN-dla-Katowic-525.html (accessed on 20th June 2017) [In Polish]. 